\title{
Managerial Family Ties and Employee Risk Bearing in Family Firms: Evidence from Spanish Car Dealers
}

\author{
Luis R. Gomez-Mejia ${ }^{1}$ | Martin Larraza-Kintana ${ }^{2}$ | Jose Moyano-Fuentes ${ }^{3}$ | Shainaz Firfiray ${ }^{4}$
}

\author{
${ }^{1}$ Deptartment of Management, Arizona State \\ University, Tempe, AZ \\ ${ }^{2}$ Dept. de Gestión de Empresas and Institute \\ for Advanced Research in Business and \\ Economics (INARBE), Universidad Pública De \\ Navarra, Pamplona (Navarra), Spain \\ ${ }^{3}$ Dept. de Organización de Empresas, \\ Marketing y Sociologia, Universidad de Jaén, \\ Linares (Jaén), Spain \\ ${ }^{4}$ Dept. of Organisation \& HRM, Warwick \\ Business School, University of Warwick, \\ Coventry, UK

\section{Correspondence} \\ Martin Larraza-Kintana, Dept. de Gestión de \\ Empresas, Universidad Pública De Navarra, \\ Campus de Arrosadia 31006, Pamplona \\ (Navarra) - Spain \\ Email: martin.larraza@unavarra.es
}

\begin{abstract}
This article argues that family firms in which the top management team (TMT) is dominated by nonfamily managers are more likely to shift risk to employees through incentive pay schemes than family firms with TMTs dominated by family members. We also argue that this tendency is aggravated in firms of bigger size, as this condition makes nonfamily managers more vulnerable. We further note that differences between family- and non-family-dominated TMTs may lessen when the sales trend is negative. The analyses conducted on a sample of 219 familycontrolled car dealerships in Spain confirm our expectations.
\end{abstract}

\section{KEYWORDS}

family firms, incentive pay, nonfamily managers, risk bearing, socioemotional wealth

\section{1 | INTRODUCTION}

A large proportion of firms around the world are controlled by families, particularly among small and medium-sized non-publicly traded firms (Laporta, López-de-Silanes, \& Shleifer, 1999). For instance, some accounts estimate that approximately 95 percent of all non-publicly traded firms in the construction and service sectors are family owned (Amit \& Villalonga, 2014). Surprisingly, the scholarly literature has not paid much attention to the human resource management practices of these firms, particularly in the domain of pay incentives, which a parallel literature suggests is a key practice affecting employee risk bearing and risk taking (Devers, McNamara, Wiseman, \& Arrfelt, 2008; Gomez-Mejia, Welbourne, \& Wiseman, 2000; Villena, Gomez-Mejia, \& Revilla, 2009; Wiseman \& Gomez-Mejia, 1998). The level of analysis has generally been at the firm level, usually comparing family and nonfamily firms, treating internal processes that may impinge on risk bearing and risk taking as a black box. This article sheds light on these issues by examining how managerial family ties influence risk bearing by managers and the cascading effect that this has on internal human resource decisions that transfer risk in the form of variable pay to lower levels in the organization.

Past research has documented that compared to their family peers, nonfamily managers bear more employment and compensation risk (Cruz, Gomez-Mejia, \& Becerra, 2010; De Kok, Uhlaner, \& Thurik, 2006; Gomez-Mejia, Larraza-Kintana, \& Makri, 2003; Gomez-Mejia,
Nuñez-Nickel, \& Gutierrez, 2001; McConaughy, 2000; Reid \& Adams, 2001). In spite of this recognition of the greater personal risk that nonfamily managers bear, no research conducted to date has analyzed the extent to which this translates into a set of human resource policies for subordinates that mirror the risks faced by nonfamily managers. Here, we argue that human resource decisions taken by nonfamily managers in family firms are strongly driven by the greater personal risk they bear relative to their counterparts with family ties to owners. More specifically, we propose that in family firms, nonfamily control of the top management team (TMT) impacts employee risk bearing through the implementation of incentive pay schemes for the entire organization. Using insights from behavioral agency theory (Wiseman \& Gomez-Mejia, 1998) and the socioemotional wealth preservation model (Gomez-Mejia, Cruz, Berrone, \& De Castro, 2011; Gomez-Mejia, Haynes, Nuñez-Nickel, Jacobson, \& Moyano-Fuentes, 2007), we contend that in doing so, nonfamily managers, who are not affected by socioemotional wealth (SEW) protection concerns, try to share and shift some of their personal risk to subordinates. We also argue that risk bearing of nonfamily managers is accentuated as the firm grows in size. This is because direct supervision of employees becomes more difficult as a firm grows, increasing the perception of a loss of control over employees (Balkin \& Gomez-Mejia, 1987, 1990; Gomez-Mejia, 1992). Consequently, an increase in firm size reinforces nonfamily managers' desire to share with and deflect some of this risk to subordinates through the compensation system. Additionally, 
we indicate that since family and nonfamily managers in family firms face prospects of severe losses in their wealth as sales decline (Chrisman \& Patel, 2012), differences in the tendency to share risk with employees tend to disappear with a negative sales trend.

The article makes several contributions to existing literature. First, it explores for the first time the impact of risk-bearing differences between family and nonfamily managers on the human resource management policies implemented for their subordinates. Second, it contributes to the growing body of research that seeks to understand the internal mechanisms that explain risk bearing, decision-making processes, and performance among family firms. Third, it focuses on the TMT as a whole, rather than on the sole figure of the CEO (e.g., Gomez-Mejia et al., 2003; Gomez-Mejia, Tosi, \& Hinkin, 1987; Martin, Wiseman, \& Gomez-Mejia, 2016). Despite the salience of the TMT in the context of a firm's operational decisions in general, and of incentive policies in particular, the family business literature has largely overlooked the study of TMTs and specifically the consequences of the relative power and influence of the two central "factions" (Li \& Hambrick, 2005) in the TMT of family firms: family and nonfamily managers. Finally, an interesting feature of the present study is that predictions are tested on a sample of 219 small and medium-sized car dealerships in Spain controlled by families. Hence, the study offers a unique glimpse at the determinants of compensation programs in privately owned service firms, as this data is not available from archival sources and it is exceedingly difficult to obtain. It also allows us to effectively control for industry and rule out the presence of other confounds that might influence incentive schemes.

\section{2 | THEORY AND HYPOTHESES}

\section{1 | Family Managers in the TMT and Risk Bearing}

Nonfamily managers differ from their family counterparts in one aspect that is essential to our understanding of the decisions they make, and particularly those related to pay: the risk they bear. Behavioral agency theory suggests that how managers frame decision situations depends on the perceived employment and compensation risk that they face (Wiseman \& Gomez-Mejia, 1998). One of the central tenets of this theory is that because agents are loss averse, when managerial wealth is perceived to be at risk (either for fear of dismissal or reduced earnings), agents will take steps to mitigate that risk whether or not such actions may represent the best options at hand (Larraza-Kintana, Wiseman, Gomez-Mejia, \& Welbourne, 2007; Gomez-Mejia et al., 2000).

In terms of employment, past empirical research has shown that executive successions, tenures, and dismissals depend on firm performance, particularly for the less powerful parties in the TMT (Boeker, 1992; Boyne, James, John, \& Petrovsky, 2010; Fee \& Hadlock, 2004). For instance, Virany, Tushman, \& Romanelli (1992) observed that for the chief executive to be dismissed, this individual must lack sufficient power to prevent his or her own ouster. Similarly, Boeker (1992) observed that powerful CEOs displace blame for poor performance onto other executives in the TMT who subsequently are replaced, while the chief executive remains.

Family TMT managers are likely to hold more power in a family firm than outsiders, and thus it is unlikely that their dismissal would even be considered except in the most extreme situations. For instance, in their longitudinal study of family-owned newspapers, Gomez-Mejia et al. (2001) report that on average, family executives stay at the helm seven years longer than nonfamily executives even when there is strong evidence that the probability of firm failure is high. Cruz et al. (2010) report that the tenure of family executives is almost four times greater than that of nonfamily executives. In addition, the relationship between nonfamily managers and the firm is often utilitarian and distant (Lubatkin, Schulze, Ling, \& Dino, 2005), lacking the emotional ties with the organization and other family members that characterize family executives (Gomez-Mejia et al., 2007). The combination of weak power and a lack of emotional ties to owners makes nonfamily managers more vulnerable than family managers such that they can be more easily scapegoated for any problems down the road, even if the source of the problems lies with the family managers themselves (Gomez-Mejia et al., 2001).

Further, it is well known that controlling families possess a tendency to protect their SEW (Gomez-Mejia et al., 2014; Gomez-Mejia, Patel, \& Zellweger, in press; Gomez-Mejia et al., 2007). Because of the control dimension of SEW, it is likely that family owners will be inclined to limit the discretion of the TMT dominated by nonfamily managers and place them under closer supervision. This greater supervision may exacerbate the perception among nonfamily managers that family owners are vigilant and ready to dismiss them if things do not turn out as expected. Not surprisingly, nonfamily managers will feel more vulnerable under these close monitoring conditions, which will also increase their perceived risk bearing. Hence, in the terminology of behavioral agency theory, nonfamily managers are more likely to frame the employment contract as a "loss context."

Compensation risk is also greater for nonfamily managers. Because of the generally unquestioned loyalty of family managers to the firm and the owners' desire to minimize conflict among relatives, family managers tend to enjoy protective compensation contracts that shield them from potential earnings losses or "downside risk" (Cruz et al., 2010). In contrast, nonfamily managers are seen as "professional resources" obtained from the open labor market whose main function is to support the family group (Heck, 1998). Consequently, their relationship with the firm is largely instrumental and their pay is pegged to their real or perceived economic contributions to the organization. Consistent with this notion, two separate studies using vastly different samples report that when compared to their family counterparts, the compensation of nonfamily managers tends to be less insulated from variations in firm performance (i.e., they assume greater risk) (Cruz et al., 2010; Gomez-Mejia et al., 2003). Interestingly, it has also been shown that compensation risk is greater for board members who do not belong to the controlling family (Muñoz-Bullón \& Sánchez-Bueno, 2014). In short, as per behavioral agency theory, greater compensation risk for nonfamily managers is more likely to place them in a "loss context" and hence energizes them to find ways to mitigate potential losses.

\section{2 | Nonfamily Managers' Transfer of Risk to Employees through Incentive Pay}

Incentive pay design is a key aspect of human resource management, as it may have a major influence on employee motivation and behavior. According to much of the compensation literature, the decision 
to implement variable pay schemes may be driven by a desire to share risks with employees (Bloom \& Michel, 2002; Martin, Wiseman, \& Gomez-Mejia, 2016, 2017; Milkovich, Newman, \& Gerhart, 2014). In the case of family firms, we propose that when the TMT is dominated by nonfamily managers, they will favor extensive use of incentive pay schemes for agents below them (i.e., employees) in anticipation that this will reduce some of the higher risk they bear.

There are several arguments to explain how the use of incentive pay schemes for employees may help reduce the risk borne by nonfamily managers. First, from an agency theory perspective (Eisenhardt, 1989), compensation, and more specifically incentive compensation, is a tool that allows principals to align the goals of the employee (i.e., agent) with their own goals by linking employee wealth with outcome measures that matter to managers (i.e., principals). Because nonfamily managers are more likely to be held answerable for poor performance and their compensation is not as isolated from variations in performance as that of their family counterparts, they should show a keen interest in ensuring that the employees' attention remains focused on attaining those outcomes that are important to the manager's own welfare. As indicated by Werner and Tosi (1995), those with stronger incentive pay at the top are likely to "cascade down" such arrangements and use more incentive pay for agents below them. Moreover, in contemporary organizations, incentive systems reward employees not merely for performance but for development of skills and problem-solving abilities. Under such a system, workers are not only incentivized on the basis of how well they are performing their current jobs but also on the basis of the jobs they are capable of doing and the depth of their knowledge (Cascio, 1995). The alignment of compensation with skills acquisition may enhance levels of employee competence and hence contribute to the organization's objectives. The extent to which individual employees have developed these skills is often evaluated through a subjective performance appraisal. Typically, the immediate supervisor is responsible for subjectively appraising subordinates (Murphy \& Cleveland, 1991). However, irrespective of who is responsible for rating employees, aligning the pay of employees to subjective performance evaluations introduces greater compensation risk and risk bearing on the agent (Gomez-Mejia, Page, \& Tornow, 1992; Gomez-Mejia et al., 2000).

Second, the compensation system can provide the TMT dominated by nonfamily managers with a direct mechanism to readily dismiss or replace subordinates that do not meet the targets as specified in the incentive contract. As an informational control tool, this feature of incentive contracts can help identify and reduce on a periodic basis real or perceived "dead weight" (Batt \& Colvin, 2011) that may prevent the nonfamily managers from meeting their goals and thus mitigate personal risk.

Third, the adoption of incentive schemes for subordinates may have a desired "impression formation" influence (Cruz et al., 2010; Judge \& Ferris, 1993; Makri, Lane, \& Gomez-Mejia, 2006) on family owners by showing them that the hired professionals in charge are doing everything in their power to ensure the sustained success of the organization. That is, having an incentive plan in place may signal to controlling owners that hired managers are trying their best to enhance the family's economic welfare. This will help nonfamily managers limit the possibility of being blamed for eventual lapses in firm performance.

Finally, and in addition to the above risk-sharing considerations, we should also bear in mind that this tendency of nonfamily TMT members to use incentive compensation for employees is further reinforced by the fact that they do not care as much as family managers about the preservation of SEW (Berrone, Cruz, GomezMejia, \& Larraza-Kintana, 2010; Gomez-Mejia, et al., 2007). For the latter group, the face of the firm is the same as the face of the family. As defined by Gomez-Mejia and colleagues (2007), SEW encompasses a broad set of affect-related aspects of the business that meet the family's emotional needs, and that by definition are deeply intertwined with family membership. Family managers will attempt to preserve this socioemotional endowment across the firm by projecting a positive family image, showing a general reluctance to adopt any practice that may be perceived as a threat to that endowment.

Heavier reliance on extrinsic incentives may diminish the family manager's image and binding social ties by creating more tension, friction, and distrust among subordinates (Cruz, Firfiray, \& Gomez-Mejia, 2011; Cruz et al., 2010). In other words, a strong emphasis on incentive pay that engenders risk for employees is likely to be inconsistent with SEW preservation. According to Werner, Tosi, and Gomez-Mejia (2005, p. 379) "incentive-based compensation schemes for employees may increase performance, yet they may reduce employee satisfaction, ... disrupt the social fabric of the organization, ... and create more tension in supervisory/employee relations and high turnover." These pay schemes transfer risk to employees because measurable outcomes are seldom under the complete control of agents and because the causes of performance variations are difficult to ascertain (Milkovich et al., 2014). In contrast, contracts with a greater percentage of fixed pay and less emphasis on incentives tied to a specific set of results are more likely to be perceived as protective of the employee's welfare and believed to engender reciprocal obligations that do not need to be enforced through formal contracts and evidence of meeting ex-ante performance expectations (Cruz et al., 2010). Hence, the adoption of incentive pay schemes for employees may be perceived as a potential threat to SEW by family managers in family firms and deter them from emphasizing these pay schemes for their subordinates. On the other hand, preservation of SEW and thus the avoidance of contracts that may impose hardships on employees (for instance, punishment for failure to meet stringent performance standards regardless of the causes) may not be the most pivotal concerns for nonfamily managers. Hence, nonfamily managers' propensity to use incentive pay schemes for employees will not be hindered by SEW protection concerns.

In sum, nonfamily managers, who are exposed to greater employment and compensation risk than their family counterparts, are more prone to "cascade down" some of that risk to lower levels within the firm (Werner \& Tosi, 1995) by implementing incentive pay schemes for their employees. Therefore, since a TMT dominated by nonfamily managers will show an inclination to attend to the goals of its nonfamily members (Minichilli, Corbetta, \& MacMillan, 2010), we argue in our first hypothesis that family firms with TMTs dominated by nonfamily managers will transfer risk to employees through the use of incentive schemes. 
Hypothesis 1: Family firms in which the TMT is dominated by nonfamily managers will transfer greater risk to employees by making more extensive use of incentive pay schemes for employees than family firms in which the TMT is dominated by family managers.

\section{3 | The Influence of Firm Size and Sales Trend on Employee Risk Bearing}

An element that may affect the perceptions of managers about the risk they bear is firm size (Wowak, Gomez-Mejia, \& Steinbach, 2017). As the firm grows in size, direct supervision of employees becomes more difficult and therefore increases the perception of a loss of control over employees. This will lead managers to perceive that employees may decrease their contribution to the firm if they are not closely monitored. That is, under the standard agency theory assumptions (Eisenhardt, 1989), the risk of employees showing opportunistic behavior (i.e., agency problem or moral hazard) increases with firm size. In turn, this perceived loss of control over employees would manifest in an increase in the risk borne by the managers because employee opportunism may harm employee productivity and firm performance, and that will put the manager's employment and compensation at stake. As per the logic and arguments summarized in Hypothesis 1, as a firm increases in size, managers will be more likely to share risk with employees through the implementation of incentive pay schemes.

The increase in risk borne associated with the loss of control over employees and the menace of opportunistic behavior that comes with bigger firm size will be particularly noticeable for nonfamily managers in the TMT. This is because, as we have already noted, they are more likely to be blamed and fired if performance does not reach the expected level in the short term (Gomez-Mejia et al., 2001). Because of bounded rationality, it may be difficult to elucidate the precise cause of negative results (Balkin, Markman, \& Gomez-Mejia, 2000; Miller, Wiseman, \& Gomez-Mejia, 2002), and hence family principals will be more likely to link it to a significant person (i.e., the CEO) or a small coalition of highly visible people (i.e., the TMT) than to specific, rather anonymous, employees. In this context also, an inference of managerial incompetence when results turn out to be poor is more likely to be made by the owning family when a nonfamily executive is at the helm; on the contrary, disappointing outcomes may be interpreted by these owners as plain bad luck when a family executive is in charge (Gomez-Mejia et al., 2001).

Any inclination felt by family managers to emphasize incentive pay schemes is likely to be tempered by the SEW protection concerns highlighted above. In addition, some of the values contained in the family's SEW such as identification with the company, or emotional attachment, may make family managers develop a more romantic view of the company's employees and see them as stewards of the organization and therefore less inclined to act opportunistically (Miller, Le Breton-Miller, \& Scholnick, 2008; Pearson \& Marler, 2010; Vallejo, 2009). The controlling family, and its managers in particular, may think that the rest of employees, even if not family members, will be as loyal as themselves to the company and therefore there will be no goal conflict between the employees, the family, and ultimately the company.

In sum, the proclivity of nonfamily managers in family firms to implement incentive pay schemes for employees should be greater as firm size increases. Hence, if the TMT is dominated by nonfamily executives, we will observe greater use of incentive pay for employees in bigger firms. This logic is captured in our second hypothesis:

Hypothesis 2: In family firms in which the TMT is dominated by nonfamily managers, the transfer of risk to employees through the use of incentive pay schemes increases with firm size.

A decline in sales (particularly for auto dealers) indicates that the firm is not doing well compared to historical standards and thus it faces a higher probability of failure or at the very least some restrictions to growth. Because nonfamily managers are more likely to be blamed for these problems (see a study by Gomez-Mejia et al., 2001, showing that in their population of newspapers the nonfamily editor was often terminated and replaced when sales declined), a decline in sales will increase the risk borne by nonfamily managers. But a decline in sales also increases the risk borne by family managers, as they may lose both the economic and socioemotional wealth endowments that are inextricably tied to the firm (Gomez-Mejia, Makri, \& Larraza-Kintana, 2010). In this vein, both family and nonfamily managers in family firms may face prospects of severe losses in their overall wealth endowment as sales decline, and therefore bear a similar amount of risk.

The literature on family firms (e.g., Chrisman \& Patel, 2012) has indicated that as the performance of family firms declines, controlling families show a tendency to shift their attention from their primary SEW reference point toward an economic reference point. Because of this shift, the behavior of family-controlled companies begins to emulate that of non-family-controlled ones in economically negative contexts. Hence, with a negative sales trend we should expect family TMT members to show preferences and therefore behavior that is similar to that of their nonfamily colleagues. Specifically, we would expect a similar tendency to diversify the risk they bear with their subordinates and therefore a greater reliance on incentive pay schemes. The personal advantages of adopting incentive pay schemes for employees, pointed out earlier, will be more salient for nonfamily and family agents as the "fear factor" gets stronger due to declining sales. In addition, the constraining effect of the SEW protection preferences weakens under a negative sales trend given that it already represents a real threat to SEW (Chrisman \& Patel, 2012; GomezMejia et al., in press). Further, a negative sales trend may be seen as a signal that existing practices are failing and therefore family TMT managers may be more likely to adopt new ones (Cyert \& March, 1992).

In sum, the inclination of nonfamily managers in family firms to implement incentive pay schemes for the workforce is similar to that of family managers as sales trend becomes stagnant or negative. Alternatively, in the context of a positive sales trend, the risk borne by family and nonfamily managers will differ. Hence, as per the arguments provided in Hypothesis 1, we will observe greater use of 
incentive compensation for employees in family firms where the TMT is dominated by nonfamily executives (as compared to family firms with a TMT dominated by family executives). This is reflected in our third and final hypothesis.

Hypothesis 3: Under a negative sales trend, the transfer of risk to employees through the use of incentive pay schemes is similar in family firms in which the TMT is dominated by nonfamily managers as well as those in which the TMT is dominated by family members.

\section{3 | METHOD}

\section{1 | Sample and Data Collection}

As indicated in the introduction, our hypotheses were tested on a sample of 219 family-controlled small and medium-sized Spanish car dealers, utilizing a combination of survey data gathered from the top manager of each car dealership in 2008 and archival data from external sources. This population offers multiple advantages for testing our hypotheses, including effective controls for industry, country, and organizational features; unambiguous designation of family ownership and managerial family ties; and access to profitability, sales, and compensation data in private firms that is very difficult to achieve in other settings.

We utilized the database of the Federación Española de Asociaciones de Concesionarios de Automoción (FACONAUTO). This federation prepares periodic reports and statistics about the automotive sector, including information about each car dealer in Spain. The initial list of firms provided by FACONAUTO was revised before we began fieldwork to guarantee that firms were still active in business. To obtain this information, we checked firm websites and personally contacted the firms by phone. Through this exhaustive and timeconsuming process, we obtained a final list of 2,156 automotive car dealers in Spain.

Before sending out the questionnaire, a draft version was tested with a panel of five renowned researchers, along with three managers working in three car dealerships associated with different car manufacturers (Peugeot, Citröen, and Renault). The questionnaires were sent to the aforementioned researchers and managers by e-mail. A form was attached to the e-mail so that the managers and researchers could include any relevant comments about item wording, content, and order within the questionnaire. All the forms were returned using the same means (e-mail) by the researchers and managers after a phone follow-up and within the expected deadline. A pilot study was then carried out in three different car dealerships to ensure that the definitions of items were meaningful and comprehensible for the sample. This assured content validity.

Simultaneously, we contacted FACONAUTO and other car dealer associations in Spain and got them involved in our research. After our contact, they were active in spreading information about our research among their members and requesting their participation.

Taking into account the nature of the information we were demanding, the top manager of each car dealer (i.e., gerente) was selected as the key informant. Top managers had the knowledge and all the information necessary to complete the questionnaire. In addition, informants higher up in the hierarchy are often considered as more reliable than those in lower hierarchical positions (Phillips, 1981). The questionnaire was sent to the top manager of each car dealer via a combination of regular mail, e-mail, and Internet-based survey methods. Attached to the questionnaire was an introductory letter highlighting the purpose and aims of the study and asking the top manager to participate, explaining that the research project was cosponsored by FACONAUTO.

After a telephone follow-up process, 247 fully completed questionnaires were obtained (11.5 percent response rate). Two hundred nineteen of those questionnaires came from car dealerships controlled by families and constitute the sample for our study. Because these were all relatively small organizations (most organizations had fewer than 100 employees), we considered a firm as controlled by a family if the family holds 50 percent or more voting stock (Westhead \& Cowling, 1998). This high proportion of family firms in the sample is fully consistent with the ownership structure in the population, where the vast majority of firms are controlled by families. The response rate was highly satisfactory considering that the response rate of the surveys and information request initiatives launched by FACONAUTO and other car dealer associations are below 10 percent.

The sample distribution of car dealers across the 52 provinces of Spain was similar to that in the population. In this vein, responses were obtained from car dealers in all the 52 provinces. Further, the provinces with a larger number of respondents were also the ones with more car dealers. More specifically, and similar to the proportions in the population, 9 percent of car dealers in the sample are located in the province of Madrid, 7 percent in Barcelona, and 5 percent in Valencia. The distribution also resembles the one that can be observed when other regional agglomerations are taken into account. For example, as in the population, 19.8 percent of car dealers are in the autonomous community of Andalucía and 10.1 percent in Cataluña. Hence, sample distribution of car dealers across geographic regions is fully consistent with the one in the population.

With regard to distribution by firm size, micro-firms (up to 10 employees) account for 12.6 percent of the sample, small firms (up to 50 employees) account for 65.2 percent of the sample, and medium-sized firms (up to 250 employees) account for 22.2 percent of the sample. This distribution of firm size in the sample is consistent with the distribution that can be found in the only available secondary data source that provides information about the size of firms in the Spanish car dealer industry: the SABI database. SABI is the most comprehensive database of firms in Spain. It shows that 78.4 percent of firms whose activity is to sell motor vehicles-which includes not only cars but also trucks, tractors, motorbikes, and so on-have fewer than 50 workers. This proportion is 77.8 percent in our sample.

We found no evidence of response bias by comparing respondents with nonrespondents. Phone calls were also made to a random selection of car dealers who did not respond to the questionnaire. We did not observe any specific characteristics in those that decided not to participate, nor any pattern in the reasons provided by them to justify their refusal to participate. In general terms, there does not 
seem to be any nonresponse bias in our sample. Finally, we compared the responses of early respondents to those provided by late respondents (Armstrong \& Overton, 1977) and found no statistically significant differences for any of the variables included in the study $(\alpha=$ .05). We conducted the corresponding mean comparisons $t$-test for all variables included in the present study and observe that all of them vary from -0.316 to -1.486 , with the $p$ values always over .14 (two-tailed tests).

\section{4 | MEASURES}

\section{1 | Dependent Variable: Employee Risk Bearing}

In order to measure our study's dependent variable, we asked participants to compare the use of a series of incentives purported to measure risk bearing for employees in their firm with the sector average on a 1 to 7 scale ( 1 = much less, $4=$ about the same, 7 = to a much greater extent). Items included in the measure (see Table 1) captured a wide array of incentive policies that according to the previous literature (Gomez-Mejia \& Balkin, 1989; Narasimhan, Swink, \& Kim, 2006; Vázquez-Bustelo, Avella, \& Fernández, 2007), as well as the opinion of participants in the survey instrument pretest are deemed as reflective of greater employee risk bearing. Given the novelty of the proposed measure, following the standard procedure we factor analyzed the responses and obtained a single factor. All items presented sufficiently high factor loadings after varimax rotation (see Table 1). This single factor is therefore capturing the extent to which the use of incentive pay schemes involving risk bearing for employees in a car dealership is higher or lower than the sector average.

We took several steps to confirm the validity and reliability of this risk-bearing measure. First, convergent validity was demonstrated by each item having loadings in excess of .5 (Bagozzi \& Yi, 1988). Second, internal consistency was tested using Cronbach's alpha. The value of the alpha (.73) exceeds the .70 cutoff that is usually considered as acceptable, particularly in early stages of research (Cruz et al., 2010; Hair, Black, Babin, \& Anderson, 2009). Third, using a split-sample agreement procedure (Larraza-Kintana et al., 2007), we found that two randomly drawn subsamples of firms $\left(N_{1}=110\right.$ and $\left.N_{2}=109\right)$ produced nearly identical results in terms of the ratings of the four compensation policies. None of the differences between the four pairs of response means were found to be statistically significant between the two random samples.
Finally, in order to further gauge the content validity of our scale as an instrument to capture employee risk bearing, we launched a separate survey addressed to 272 academic experts on the subject of compensation. Each of these experts had published at least one paper on incentives and rewards in top-tier management journals (for a list of these journals see Treviño, Gomez-Mejia, Balkin, \& Mixon, in press; see also Gomez-Mejia \& Balkin, 1992) during the past 15 years. In addition, we included authors of compensation-related articles appearing in Human Resource Management and/or presented in the 2012 Academy of Management annual meeting. One hundred forty experts responded to the questionnaire $51.5 \%$ response rate, which is very high considering that some of the individuals targeted were no longer available due to retirements, death, sabbaticals, etc.). The questionnaire, previously pretested on a panel of six compensation scholars who also had extensive consulting experience (see appendix), was finally composed of eight items. The experts were asked:

For each of the following personnel practices please indicate the extent to which you agree that its use implies greater risk bearing for employees. Risk bearing refers to the extent to which a particular human resource practice has some real or perceived downside for employees such as failure to meet more stringent expectations, being held accountable for results that may be beyond the employees' control, uncertainty in future earnings, increased anxiety about job security and the possibility of receiving poorer performance ratings.

The response format consisted of a 5-point rating scale ranging from "strongly disagree" to "strongly agree."

We first factor analyzed the responses from the 140 compensation experts and obtained two factors that capture 57.38 percent of total variance. Confirmatory factor analyses further support the existence of these two factors. The first factor was composed entirely of the four items in the original survey of car dealers, which provides evidence in support of the discriminant validity of the construct and also cross-validates the four-item risk-bearing scale in two completely different samples. Importantly, the reliability value for the first factor (.76) among the compensation experts is very similar to that obtained in the original sample of car dealers (.73).

Second, we compared the ratings of experts concerning the perceived level of employee risk bearing associated with the items in

TABLE 1 Employee Risk Bearing through the Use of Incentive Pay Schemes

\begin{tabular}{|c|c|c|c|c|}
\hline Item & Item Average & Factor Loading & Factor Average & Cronbach's Alpha \\
\hline $\begin{array}{l}\text { Employees receive incentive payments if they show evidence that they } \\
\text { have acquired new skills and knowledge to perform their jobs better. }\end{array}$ & 3.54 & .79 & & \\
\hline $\begin{array}{l}\text { Employees receive incentive payments if they show evidence that they } \\
\text { can resolve important work-related problems. }\end{array}$ & 3.27 & .82 & & \\
\hline $\begin{array}{l}\text { Employees receive incentive payments when they achieve objectives or } \\
\text { targets set by their employer. }\end{array}$ & 4.87 & .65 & 4.01 & .73 \\
\hline $\begin{array}{l}\text { Employees receive incentive payments based on their individual } \\
\text { performance as well as the performance of their team. }\end{array}$ & 4.38 & .72 & & \\
\hline Mean for nonfamily dominance of the TMTs & & & 4.33 & \\
\hline Mean for family dominance of the TMTs & & & 3.82 & \\
\hline
\end{tabular}


factors one and two. The average score for the items in the first factor (i.e., employee risk-bearing scale used in the paper) is a full 1.50 point higher than the average score of the items in the second factor (i.e., 3.6 vs. 2.1, $p<.0001$ ). Hence, on average the 140 experts strongly discriminated the risk-bearing properties of the first four items (the ones used with the car dealers) from the other four items (the ones used for comparison purposes in the survey of compensation scholars). Finally, a split sample analysis ( $N=70$ each) indicated that none of the mean differences in the perceived risk-bearing items between the two groups was statistically significant, indicating a high degree of interrater reliability among the experts as to the riskbearing properties of each item.

In sum, taking all of the above into consideration, we feel very confident about the validity and reliability of the employee riskbearing scale used in the study; thus, the higher the score of these items, the more likely management is transferring risk to employees through the incentive system.

\section{2 | Independent Variables}

\subsubsection{Nonfamily Dominance of the TMT}

Respondents were asked to indicate whether the majority of management positions in the family firm were occupied by family members. Based on the responses to this question, we created a dummy variable that takes a value of 1 when the majority of the TMT positions are occupied by non-family members and zero when the majority of those management positions are held by family members.

This variable, which takes into account the proportion of family and nonfamily members in the TMT, is similar to others used in previous research (e.g., Chirico \& Bau, 2014; Minichilli et al., 2010). Primary sources of information on the family and non-family members of the TMT are considered to be more accurate than secondary ones, which can only estimate family membership based solely on the family name (Minichilli et al., 2010). Additionally, in our case, the information about TMT composition available in secondary sources covered only a small number of firms in the sample.

Note that because firms in our sample are undiversified small to medium-sized firms, with very simple organizational structures, their management teams are usually composed of a small number of individuals. On average, management teams in our sample have three members, and 75 percent of the management teams have fewer than four members. Hence, it was quite straightforward for respondents to determine whether the majority of the management team were family members or not. In addition, in this context, control by nonfamily managers can be effective because when respondents indicate that the majority of management positions are held by nonfamily managers, they are saying that in the average car dealership, at least a percentage of the management team, as high as two-thirds (two managers), does not belong to the controlling family. It must be noted that the information was provided by the senior member of the management team (i.e., top manager), who should be fully aware of family status. Finally, we should note that we checked the family membership of the CEO and the TMT against an independent source, the SABI database, and found that when the TMT is dominated by family members, it is rare to find a nonfamily CEO at the helm (this occurs in only about 10 percent of cases). However, when the TMT is dominated by nonfamily managers, it is not uncommon to find either a family or nonfamily CEO at the helm. The main factor that explains our results (to be described later) is the family composition of the TMT rather than the family status of CEO.

\subsubsection{Firm Size}

We measured it in terms of the number of workers employed by the car dealer. Information was retrieved from the survey instrument.

\subsection{3 | Sales Trend}

We measured sales trend following Lamont and Anderson (1985) and Barney, Edwards, and Ringleb (1992) as the logarithm of the ratio of sales at year $t$ to sales at year $t-1$. Negative values indicate a negative sales trend, while positive ones are representative of a positive sales trend. Also, the greater the magnitude the stronger the trend. Data to compute this measure were obtained from the SABI database.

\section{3 | Control Variables}

We include in the study a set of variables that may help explain the decisions made by family firms, and particularly those that concern employee compensation. Specifically, we control for firm age, whether the car dealer commercializes more than one brand, and whether the firm is part of a group of firms (Baker, Jensen, \& Murphy, 1988; Brass, 1995; Gomez-Mejia et al., 2003; Verhoef, Langerak, \& Donkers, 2007). Firm age is measured as the number of years that have passed since the firm was founded (reference year was 2008). In the case of family firms, it implicitly controls for family tenure. Multibrand car dealer is a proxy of the degree of specialization of the car dealer. It takes a value of 1 if the car dealer commercializes more than one brand and 0 if it commercializes only one brand. As being part of a network may provide the firm with access to a source of information about organizational practices such as incentive pay schemes (Brass, 1995), we also include the variable integrated in group. It is a dummy variable that takes a value of 1 if the car dealer is part of a group of car dealers with the same controlling owner and 0 otherwise. It can be seen as a measure of the degree of horizontal integration of the car dealer. Finally, we include a dummy variable that indicates whether the incentive pay practices being analyzed had been implemented for more (1) or less (0) than three years.

Table 2 presents the descriptive statistics and correlations between the variables used in the analysis. The table shows that there are some significant correlations between the variables included in the analysis. In particular, and consistent with Hypothesis 1 , there is a positive and significant correlation between nonfamily dominance of TMT and employee risk bearing.

\section{4 $\mid$ Model Evaluation}

Hierarchical regression analysis was used to test the hypotheses developed in the article. This analysis allows the variance percentage explained by each of the independent variables to be identified separately. To test the three hypotheses, the independent variables were 
TABLE 2 Means, Standard Deviations, and Pearson Correlation Coefficients

\begin{tabular}{|c|c|c|c|c|c|c|c|c|c|}
\hline Variable & Mean & SD & 1 & 2 & 3 & 4 & 5 & 6 & 7 \\
\hline 1. Firm's age & 22.6 & 13.6 & & & & & & & \\
\hline 2. Multibrand car dealer & .19 & .39 & -.01 & & & & & & \\
\hline 4. Incentive years & .53 & .50 & $.23^{*}$ & .08 & -.05 & & & & \\
\hline 5. Nonfamily dominance of TMT & .32 & .47 & .06 & .01 & $.24 * *$ & -.06 & & & \\
\hline 6. Firm size & 40.8 & 41.0 & $.25^{* *}$ & .11 & -.01 & .10 & $.15^{*}$ & & \\
\hline 8. Employee risk bearing & 2.94 & .91 & .00 & .07 & -.02 & .00 & $.19 *$ & $.18 *$ & .05 \\
\hline
\end{tabular}

$N=219 ; *$ Correlations are significant for $p<.05 ; * *$ Correlations are significant for $p<.01$.

included separately, one by one (see Table 3), beginning with the control variables (Model 1). Next, the variable capturing nonfamily dominance of TMT was included (Model 2), followed by the variable measuring firm size and the joint effect of firm size and non-familydominated TMT members (Model 3). Model 4 adds the sales trend variable and the joint effect of sales trend and nonfamily dominance of TMT to the specification of Model 2. Finally, in Model 5, we add to Model 2 the influence of firm size and sales trend as well as their respective interactions with non-family-dominated TMT. Continuous variables were centered before creating the moderating measures. Table 3 also scores the contributions made by each set of variables by determining the change in $R^{2}$ after each set was included.

\section{5 | RESULTS}

Table 3 shows the results of the hierarchical regression analysis. Model 2 shows that nonfamily dominance of the TMT in the family firm has a positive and significant influence on employee risk bearing $(\beta=.210, p<.05)$. This effect is still significant in Models 3 and 4 , and marginally significant in Model 5 . Together, this provides support for Hypothesis 1.

Models 3 and 5 show that firm size alone does not have a significant effect on employee risk bearing. However, the interaction effect (firm size $\times$ nonfamily dominance of TMT) shows positive and significant effects in Models 3 and 5 ( $\beta=.163$ and $\beta=.215$, respectively; $p<.05$ ). This implies that the inclination of nonfamily managers to transfer risk to employees increases with firm size, which supports Hypothesis 2.

Sales trend has a negative impact on the dependent variable that is nonsignificant in Model 4 and only marginally significant in Model 5. However, the interaction effect (sales trend $x$ non-family dominance of TMT) shows a positive and significant effect in both models $(\beta=.301$ and $\beta=.365$, respectively; $p<.05$ ). This result indicates that while under a positive sales trend non-family-dominated TMT may increase the use of incentive pay schemes and the risk transfer it implies, under a negative sales trend the difference with family dominated TMTs is reduced, ${ }^{8}$ which would be consistent with Hypothesis 3. Variance inflation factors range between 1.1 and 3.4, showing that multicollinearity is not an issue in any of the models described above (Hair et al., 2009).

To better gauge the results of the interaction term, and following conventional procedures, we plot the interaction terms. More specifically, we use the nonstandardized coefficients from Models 3 and 4 and evaluate control variables at their means, while allowing firm size (Figure 1) and sales trend (Figure 2) to take values in the minus one standard deviation-plus one standard deviation range. As can be seen from those figures, the differences in employee risk bearing between family firms whose TMTs are dominated by nonfamily managers and

TABLE 3 Linear Regression Models for the Impact of Nonfamily Dominance of the TMT on Employee Risk Bearing through the Use of Incentive Pay Schemes in Family Firms ${ }^{\mathrm{a}}$

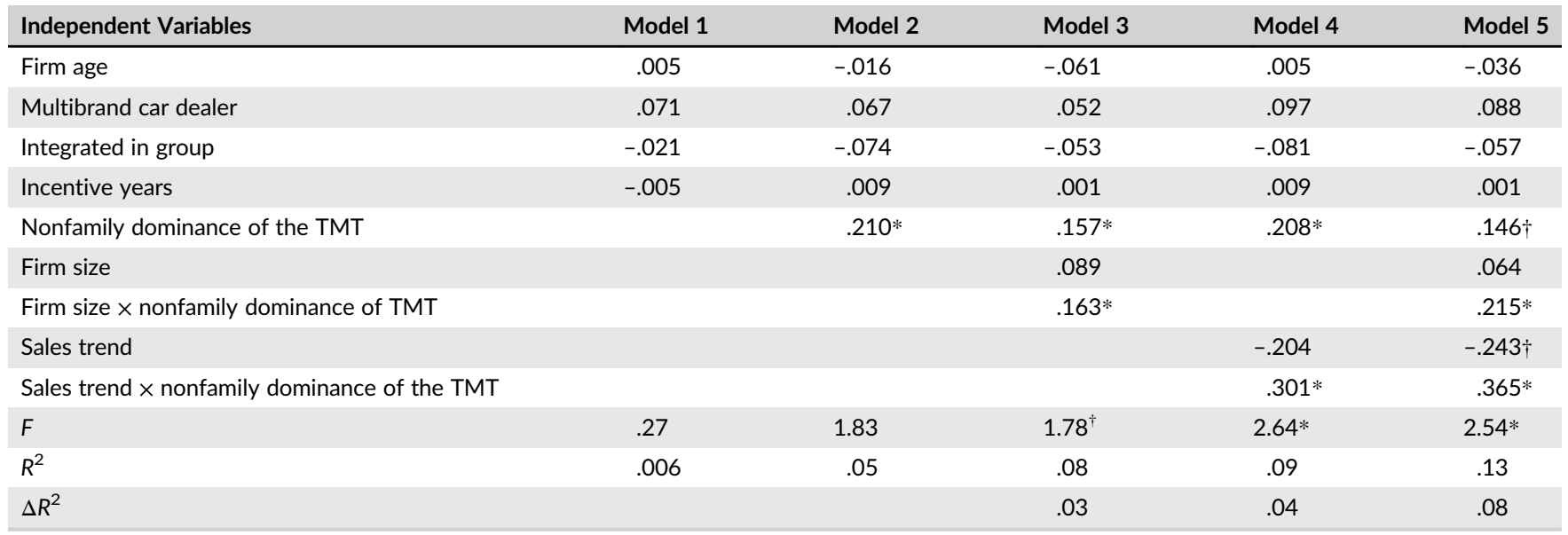

a The values are standardized regression coefficients $(\beta \mathrm{s})$.

$p<.10 ; * p<.05 ; * * p<.01$. Changes in $R^{2}$ are calculated comparing Models 3, 4, and 5 with Model 2. 


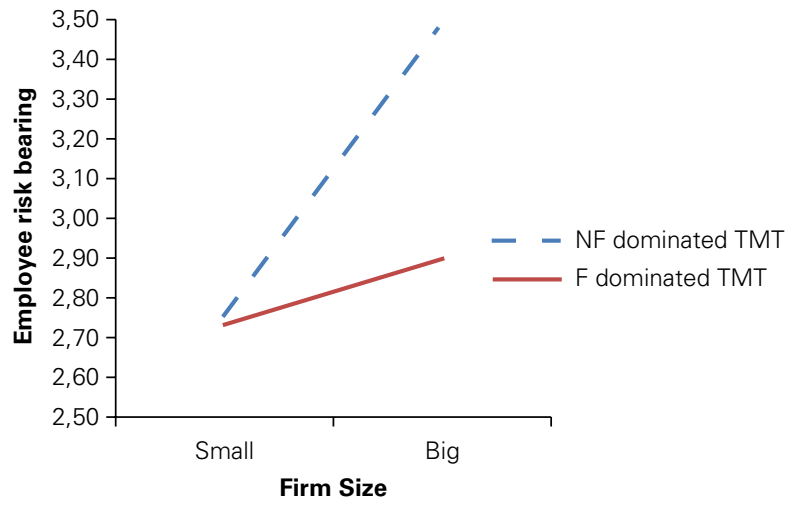

FIGURE 1 Nonfamily Dominance of the TMT, Firm Size, and Employee Risk Bearing

those dominated by family managers are in fact contingent upon firm size and sales trend. Graphs suggest that when firm size is small and sales trend is negative, there are almost no differences between the two groups. Figure 1 shows that the propensity to use incentive pay schemes for employees increases with size, particularly in the case of family firms with a TMT dominated by nonfamily managers. Figure 2 indicates that while the propensity of TMTs dominated by nonfamily managers to use incentive pay schemes for employees increases under an upward sales trend and high profitability, for TMTs controlled by family managers it decreases. Hence, Figures 1 and 2 are fully consistent with Hypotheses 2 and 3, respectively.

\section{6 | DISCUSSION AND CONCLUSIONS}

This study is aimed at understanding the effects of managerial family ties on a firm's human resource policies. Specifically, we looked at the impact that the widely reported differences in the risk borne by nonfamily and family managers in family firms had on employee risk bearing through the adoption of incentive pay schemes for subordinates. Using insights from the behavioral agency and the SEW preservation models, this article has argued and shown that greater risk bearing by nonfamily managers in the TMT of family firms results in risk transfer to employees through greater reliance on incentive pay schemes. This is the first study that has focused on the role of managerial family

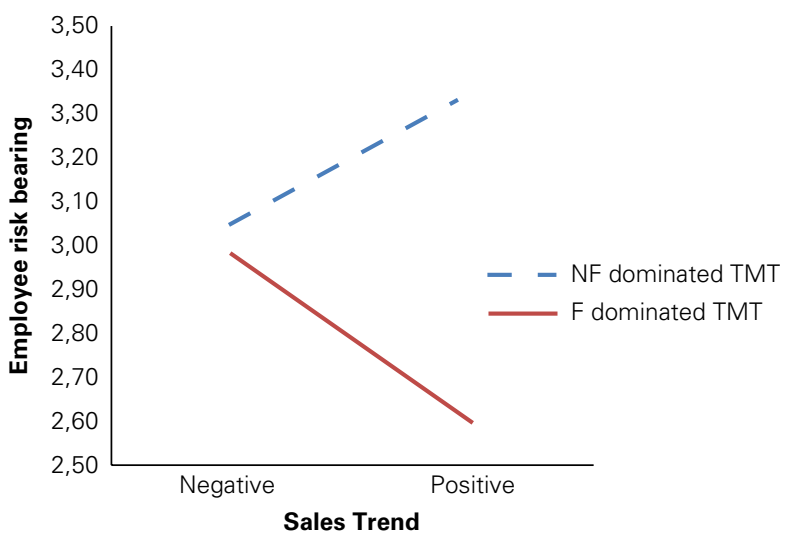

FIGURE 2 Nonfamily Dominance of the TMT, Sales Trend, and Employee Risk Bearing ties to explain how variable pay and risk bearing at the top management levels has a cascading effect on incentive systems at lower levels (Werner \& Tosi, 1995). In doing so, we have contributed to efforts aimed at disentangling the mechanisms that explain the human resource decisions taken within family firms as a function of managerial family ties with dominant principals. Our study stresses the importance of individual preferences and employment conditions to understand decisions within firms, and particularly those related to the implementation of human resource practices. As noted, in our study the desire among nonfamily managers to diminish their compensation and employment risk favors the implementation of incentive pay schemes for employees. We encourage future research to continue exploring the consequences for family firms of the differences in the risk borne by family and nonfamily managers. As noted in the introduction, the study of human resource practices in family firms represents an important contribution in itself given the overwhelming prevalence of this ownership form and the paucity of HR research in this unique phenomenological context.

Firm size is a key element when it comes to nonfamily top managers' inclination to transfer risk through the use of incentive pay schemes for employees. We have argued that as a firm grows in size the propensity of nonfamily managers in family firms to transfer risk to employees through the use of incentive pay schemes increases. This increase is grounded in perceptions of a loss of control over employees associated with a larger firm size. Consistent with this expectation, we have observed how employee risk bearing associated with the use of incentive pay schemes increases with the size of the family firm and that such an increase is significantly greater when the TMT is dominated by nonfamily managers. At this point, it may be worth considering that our sample was composed of small and medium-sized firms. Therefore, the linear growth observed in our sample may not continue beyond the spectrum of firm sizes covered within our sample. It may be interesting to analyze in future studies whether the differences in risk transfer to employees by family and non-family-dominated TMTs still hold in samples of larger firms.

We have also confirmed that the differences between family and nonfamily managers in the tendency to use incentive schemes closes with declining firm sales. Declining sales may be interpreted as a situation with poor growth prospects and a real or perceived danger of catastrophic firm failure. In this situation, both family and nonfamily managers face the prospect of losses in their wealth that seem to favor the use of incentive pay schemes for employees in family firms led by TMTs dominated by family as well as those dominated by nonfamily managers. This is consistent with previous evidence showing that as performance worsens, family members tend to shift their attention to economic reference points (Chrisman \& Patel, 2012; Gomez-Mejia et al., 2014; Gomez-Mejia et al., in press). Figure 1 and the parameter estimates of Model 5 support the idea that in cases of a downward sales trend family and nonfamily managers' predisposition to transfer risk to subordinates through the use of incentive pay schemes is similar.

As the sales trend improves, we observe a greater use of incentive pay schemes for employees (i.e., greater risk bearing) in those family firms with a TMT dominated by nonfamily members. Interestingly, Figure 2 shows that the trend is the opposite when the TMT is 
dominated by family members. This leads to a situation (see Figure 2 ) in which the biggest difference in employee risk bearing between family and non-family-dominated TMT occurs under a positive sales trend. Albeit somewhat speculative, we think this evidence may be a further manifestation of the differences in risk bearing and risk transfer preferences between family and nonfamily executives highlighted throughout the article. A positive sales trend may just provide a fertile ground for managers to implement the policies they prefer, without being pressured by market competition and uneasy stakeholders. Good performance (reflected in a positive sales trend) carries the benefit of trust in the eyes of principals and a reputation of high managerial competence (Carpenter \& Golden, 1997; Mayer, Davis, \& Schoorman, 1995). This in turn may allow nonfamily managers to more easily justify or legitimize to family principals the purported performance enhancing attributes of incentive pay schemes. In addition, good sales figures may enlarge the basis of resources available for incentive allocation, thereby making a variable pay policy more attractive and less stressful for subordinates (Werner et al., 2005); this in turn makes it easier for the nonfamily manager to implement incentive programs. Family managers, on the other hand, may perceive the positive situation as an opportunity to reduce pressure over employees and try to guarantee their loyalty through more stable forms of reward that may even include guarantees of job security.

Of course, it might be true that the chain of causality is reversed so that improved sales result from the use of incentives or that there is reciprocal causation between this set of variables. Apart from the empirical difficulty of unraveling this causal incentive-performance quagmire given the myriads of factors that influence firm performance, and sales figures (Gomez-Mejia, Berrone, \& Franco-Santos, 2010), we could not muster any reasonable arguments as to why the causal effect would be stronger in the case of nonfamily compared to family management. Furthermore, the reader is reminded that we have measured sales trend from archival sources, years prior to the survey, and thus the reverse causality interpretation is on shaky grounds. In addition, we calculated a multivariate model to predict future firm profitability (measured one or two years after the survey) and found that the effect of employee risk bearing on subsequent firm profitability was nonsignificant. This suggests that the incentive policies do not seem to lead to a financial payoff but rather may be put into place to protect nonfamily managers and thus shield them from the risk they bear. Thus, all things considered, our first explanation that does not involve reverse or reciprocal causation seems more plausible.

The more extensive use of incentive pay schemes in firms managed by nonfamily members documented in this article may also accommodate an alternative interpretation. Prior literature has indicated that while controlling families are reluctant to hire nonfamily managers, they can also bring in new ideas and foster the implementation of programs used by other firms in the industry (Bruque \& Moyano, 2007; Chrisman, Chua, \& Litz, 2003). Therefore, in this context, it could be argued that the greater use of incentive pay schemes in firms controlled by nonfamily managers may be just the reflection of those externally recruited executives bringing new ideas through the introduction of sophisticated human resource management practices. While this hypothesis is difficult to rule out completely with the information at hand (i.e., without a direct measure of the knowledge of the manager), incentive compensation has been on the rise in recent years, with a cadre of consultants predicting its value (GomezMejia, Berrone, \& Franco-Santos, 2010), and hence, it seems reasonable that nonfamily managers may be more likely to adopt this practice.

Interestingly, it should be noted that in a separate analysis, we observed that the dominance of nonfamily managers of the TMT of family firms was not significantly related with the use of other human resource management practices that can be classified as advanced according to the literature on strategic human resource management (e.g., Datta, Guthrie, \& Wright, 2005). Specifically, we analyzed the application of employee development and empowerment policies. The fact that differences in the policies adopted according to family status seem to be focused on incentive plans is consistent with our theoretical explanation about the desire among risk-bearing nonfamily managers to mitigate personal risk.

At this point, it is worth noting that all of the firms in our sample were service firms. Specifically, they were all firms in a single sector: car dealerships. Research on firm decision making in general, and on the use of human resource management practices in particular, has tended to focus on the manufacturing industry (e.g., Datta et al., 2005; Gomez-Mejia, 1988) with little research within the service industry. This raises a red flag in that the findings from the manufacturing industry may not generalize to service settings because of differences in occupational distribution, work processes, varying levels of interdependence with colleagues, and the role of the customer. Service settings, in particular, are characterized by a strong emphasis on firm-specific human capital because of their reliance on the customer-employee interface for successful operations (Mills, Chase, \& Marguiles, 1983). Thus, managers in such firms require not only knowledge pertaining to the demand characteristics of particular individuals or segments but also specific knowledge of the structure and content of the firm's information systems, the work flow from the point of sales to delivery, and how the company's processing capabilities affect each customer and product offering (Batt, 2002). In this context, this article has provided new evidence to increase our understanding of human resource practices in service firms.

Finally, in this study we have used the construct of SEW in a global sense rather than focusing on various SEW aspects such as family control and influence, family members' identification with the firm, binding social ties, emotional attachment, and renewal of family bonds to the firm through dynastic succession (Berrone, Cruz, \& Gomez-Mejia, 2012). Chua, Chrisman, and DeMassis (2015); Miller and LeBreton-Miller (2014); and Schulze and Kellermanns (2015), among others, warn us that treating SEW as a monolithic concept prevents researchers from mapping out how SEW dimensions interact with each other, overlooking how family managers prioritize the protection of those different SEW dimensions or how these priorities evolve across generations and members of the same family. This in turn makes it difficult to establish clear cause-and-effect connections between SEW and firm actions (Miller \& Le-Breton-Miller, 2014). Furthermore, SEW may be better represented as a dynamic endowment involving both stocks and flows, with its value and relevance varying over time and across generations (Chua et al., 2015). While it is 
worthwhile to keep these warnings in mind (because supportive findings cannot be interpreted precisely), treatment of SEW as a global latent construct has proven to be its key strength. It has become part of a theoretical framework allowing for the prediction of a wide variety of organizational decisions that make family firms unique, with an impressive accumulation of empirical evidence. Furthermore, we suspect it would be exceedingly difficult to precisely isolate the effect of one specific SEW dimension (e.g., control) from others (e.g., identification with the firm) on a dependent variable of interest, and the veracity of inferred processes attributed to one specific SEW dimension in a stock or flow mode is almost certain to invite questioning by a skeptical audience. Relatedly, establishing the construct validity of fine-grained SEW measures remains an elusive goal.

\section{1 | Practical Implications}

Our findings provide family owners and managers with valuable insights on how dominance of nonfamily managers on the TMT of family firms influences the use of incentive pay schemes for employees. Prior literature has recognized that compared to family managers, nonfamily managers face a higher degree of employment and compensation risk within family business settings. Yet whether this actually results in a higher propensity to increase risk bearing at lower levels through the introduction of individual performance-based incentive schemes is not clear. We illustrate that the higher risk borne by nonfamily managers causes them to introduce performance-based incentives for lower-level employees, hence subjecting them to greater risk bearing. However, individual performance-based incentives have both a bright and a dark side. They are said to have sorting effects or the ability to attract, motivate, and retain the most competent and productive workers (Lazear, 2000). On the downside, they also have several adverse consequences for employee morale, such as high stress or disruption in family life (Gerhart \& Fang, 2014). For nonfamily managers, an awareness that they possess such a bias will make them more vigilant of the potential negative repercussions of introducing such incentives for employees.

Owning families that are concerned about preservation of their socioemotional wealth or SEW can make nonfamily managers aware of this bias for passing their risk to subordinates. They can also make an additional effort to train nonfamily managers to endeavor to adopt incentive schemes and other human resource practices that not only increase productivity but also enhance employee perceptions of fairness and job satisfaction. All this can help in the preservation of the family firm's SEW. Family businesses could also invest in socialization programs for nonfamily managers that could reduce their risk-bearing perceptions and make them feel like valued members of the family business, hence leading them to make decisions that are well aligned with the family firm's objective of protecting their SEW. Boards of directors and family councils may play a pivotal role in this matter (Blumentritt, Keyt, \& Astrachan, 2007). To successfully achieve this, family firms will also need to take special measures to ensure a better level of job security for nonfamily managers and ensure that they do not face arbitrary dismissal.
Another crucial management implication suggested by our study is that a positive sales trend increases the nonfamily managers' propensity to implement employee incentive schemes. We interpret this result as a reflection of their desire to share the risk they bear with their employees. However, because of this willingness, the owning family should be particularly vigilant of their incentive policy under a negative sales trend. In this context, nonfamily managers may face heightened pressures to ensure high levels of productivity from their staff and to search for alternative ways to boost sales. One possible way of achieving this would be the implementation of incentive schemes for employees, which may motivate them to meet their targets and improve sales activity. While the controlling family may accept this policy in a negative context (as reflected in the willingness of family-controlled TMT to share risk with employees under a negative sales trend), they should be wary of transferring excessive risk to employees, as under a negative sales trend the risk transferred by each unit of incentive pay is bigger (Bloom \& Milkovich, 1998; Miller et al., 2002). Excessive risk transfer may have unintended consequences on employee behavior and deplete the family firm's SEW.

Conversely, family managers are less inclined to introduce incentives under a positive sales trend. Introduction of incentive systems may have a negative impact on the successful achievement of the SEW objectives of the owning family (such as a positive family image, a caring organizational climate, and cohesive social ties within the firm; Berrone et al., 2012). This difference in behavior among family and nonfamily managers is tied to the identity overlap between the manager and the firm (Dyer \& Whetten, 2006). Identity overlaps, which are formed due to inextricable ties between the controlling family and the firm, create a level of affect and concern for the employee and its perception in the public that is absent among nonfamily managers. However, if appropriately implemented, incentives may be positive for family firm performance, competitive advantage and ultimately survival (Astrachan \& Kolenko, 1994; Gomez-Mejia, Berrone, \& Franco-Santos, 2010). Hence, paradoxically, ignoring the potential positive effect of incentive systems may have a negative effect on long-term survival of the company, which, of course, is a necessary prerequisite for the preservation of family's SEW embedded in the firm. That is, an excessive focus on SEW protection by family managers may lead to the avoidance of well-designed incentive systems that might enhance firm performance, and this in turn may harm both the family's economic welfare and SEW in the long term. In conclusion, we are not suggesting that family firms should avoid performance-based incentives or any other HR practices that may potentially harm the firm's SEW but we concur with the views of Brickson (2007) and Zellweger, Nason, Nordqvist, and Brush (2013) that even the most nonfinancially motivated family firms will have to perform a "hedonic calculus" to evaluate potential harm incurred in the process of focusing on these goals.

\section{2 | Limitations}

Of course, our study is not free of limitations. First, we cannot directly measure what is in the minds of family and nonfamily managers when they choose to adopt or avoid incentive pay for subordinates. Our interpretation concerning the differential preferences and 
risk bearing of family and nonfamily managers as predictors of subordinates' pay mix is based on theoretical arguments deduced from the family and behavioral agency literature, but these psychological explanations still remain inferential. At the same time, it is important to recognize that most (if not all) of the published behavioral agency literature on risk bearing and risk taking has used distant archival proxies for these constructs (e.g., Bloom \& Milkovich, 1998; Chrisman \& Patel, 2012; Martin, Gomez-Mejia, \& Wiseman, 2013; Wiseman \& Bromiley, 1996), and one of the methodological contributions of this study is the development of a valid and reliable measure of compensation risk bearing for employees as agents.

Second, it is possible that there are differences across firms in the specific features of the incentive contract that make them more or less risky for employees (such as more challenging performance targets in some firms than others). Unfortunately, we had no access to a more fine-grained measure that indicated the precise nature of the incentive program. At the same time, we can't think of any reason why these differences, if any, would not be randomized across firms where nonfamily managers are at the helm and hence should not pose a major validity threat to our conclusions. In addition, we cannot gauge whether risk bearing could be changed in the short term to adjust to changes in sales trend. While adjustments are possible, they are probably unlikely to be made frequently, as too many changes may confuse the employees and leave the impression that the system is unpredictable and unreliable. Maybe at this point it is interesting to recall that in our analyses we have included a variable that captures whether the incentive pay practices being analyzed have been in place for more or less than three years. While indirect, this control variable can be seen as a rough proxy of the stability of the system.

Third, our response rate (11.5 percent) may raise questions about the strength of our results. While we obviously would have liked to obtain a bigger response rate, it is worth noting that our sample is representative of the population and that the associations working in the industry considered it, based on their own experience, as a highly satisfactory response rate. Further, response rates of around 10 percent are considered normal in mail surveys addressed to top managers (Larraza-Kintana et al., 2007).

Finally, and relatedly, as we have pointed out before, our analysis has provided evidence from an unexplored population of small to medium-sized, privately owned service firms in a narrow sector (car dealerships) from a single country (Spain). While this is a clear strength of our work, we should be cautious in generalizing our conclusions to other settings. Clearly, future studies will benefit from analyzing how risk bearing and risk preferences are influenced by the potential role played by the demographic composition of the workforce (e.g., gender; Gomez-Mejia, 1983; Huang \& Kisgen, 2013), the occupational distribution of the workforce (Gomez-Mejia, 1984), and cross-cultural factors (Gomez-Mejia, Wiseman, \& Johnson, 2005; Wiseman, Cuevas-Rodriguez, \& Gomez-Mejia, 2012).

In sum, this article sheds new light on the key role played by nonfamily managers in family firms. Theories aimed at understanding the decisions made by family firms need to take into account the presence of nonfamily actors within the firm. More specifically, they should consider whether firm management is in the hands of family or nonfamily members.

\section{ACKNOWLEDGMENTS}

Martin Larraza-Kintana acknowledges financial support by the Spanish Ministry of Economy and Competitiveness research project ECO2013-48496-C4-2-R. Jose Moyano-Fuentes acknowledges financial support by the BBVA Foundation research project obtained in the First Call of BBVA Foundation Grants for Research Projects (Socio Economics Area).

\section{NOTE}

1 It could be argued that the non-family control of management positions in the TMT is due to unobservable variables that are also correlated with our dependent variable-employee risk bearing. To analyze this issue we estimated a treatment regression model that allows us to assess whether our results may be biased by the potential endogenous character of the non-family-dominated TMT variable. The results, available from the authors upon request, were fully consistent with the results reported here.

\section{REFERENCES}

Amit, R., \& Villalonga, B. (2014). Financial performance of family firms. In L. Melin, M. Nodqvist, \& P. Sharma (Eds). The Sage handbook of family business (pp. 157-178). Los Angeles, CA: Sage.

Armstrong, J. S., \& Overton, T. S. (1977). Estimating non-response bias in mail surveys. Journal of Marketing Research, 14, 396-402.

Astrachan, J. H., \& Kolenko, T., (1994). A neglected factor explaining family business success: Human resource practices. Family Business Review, 7, 251-262.

Bagozzi, R. P., \& Yi, Y. (1988). On the evaluation of structural equation models. Journal of the Academy of Marketing Science, 16, 74-94.

Baker, G. B., Jensen, M. C., \& Murphy, K. J. (1988). Compensation and incentives. Practice vs theory. Journal of Finance, 43, 593-616.

Balkin, D. B., \& Gomez-Mejia, L. R. (1987). Toward a contingency theory of compensation strategy. Strategic Management Journal, 8, 169-182.

Balkin, D. B., \& Gomez-Mejia, L. R. (1990). The relationship between organizational strategy, pay strategy and compensation effectiveness. Strategic Management Journal, 11, 153-169.

Balkin, D. B., Markman, G., \& Gomez-Mejia, L. R. (2000). Is CEO pay related to innovation in high technology firms?. Academy of Management Journal, 43, 30-41.

Barney, J. B., Edwards, F. L., \& Ringleb, A. H. (1992). Organizational responses to legal liability: Employee exposure to hazardous materials, vertical integration, and small firm production. Academy of Management Journal, 35, 328-349.

Batt, R. (2002). Managing customer services: Human resource practices, quit rates and sales growth. Academy of Management Journal, 45, 587-597.

Batt, R., \& Colvin, A. J. (2011). An employment systems approach to turnover: Human resources practices, quits, dismissals, and performance. Academy of Management Journal, 54, 695-717.

Berrone, P., Cruz, C., \& Gomez-Mejia, L. (2012). Socioemotional wealth in family firms theoretical dimensions, assessment approaches, and agenda for future research. Family Business Review, 25(3), 258-279.

Berrone, P., Cruz, C., Gomez-Mejia, L. R., \& Larraza-Kintana, M. (2010). Socioemotional wealth and corporate responses to institutional pressures: Do family controlled firms pollute less? Administrative Science Quarterly, 55, 82-113.

Bloom, M., \& Michel, J. G. (2002). The relationships among organizational context, pay dispersion, and managerial turnover. Academy of Management Journal, 45, 33-42.

Bloom, M., \& Milkovich, G. T. (1998). Relationships among risk, incentive pay and organizational performance. Academy of Management Journal, 41, 283-297. 
Blumentritt, T., Keyt, A., \& Astrachan, J. (2007). Creating an environment for successful nonfamily CEOs: An exploratory study of good principals. Family Business Review, 20(4), 321-335.

Boeker, W. (1992). Power and managerial dismissal: Scapegoating at the top. Administrative Science Quarterly, 37, 400-421.

Boyne, G. A., James, O., John, P., \& Petrovsky, N. (2010). Does public service performance affect top management turnover? Journal of Public Administration Research and Theory, 20, 1261-1279.

Brass, D. J. (1995). A social network perspective on human resources management. In G. R. Ferris (Ed.), Research in personnel and human resources management (pp. 39-79). Greenwich, CT: JAI Press.

Brickson, S. L. (2007). Organizational identity orientation: The genesis of the role of the firm and distinct forms of social value. Academy of Management Review, 32, 864-888.

Bruque, S., \& Moyano, J. (2007). Organisational determinants of information technology adoption and implementation in SMEs: The case of family and cooperative firms. Technovation, 27, 241-253.

Carpenter, M. A., \& Golden, B. R. (1997). Perceived managerial discretion: A study of cause and effect. Strategic Management Journal, 18, 187-206.

Cascio, W. F. (1995). Whither industrial and organizational psychology in a changing world of work? American Psychologist, 50, 928-939.

Chirico, F., \& Bau, M. (2014). Is the family an "asset" or "liability" for firm performance? The moderating role of environmental dynamism. Journal of Small Business Management, 52, 210-225.

Chrisman, J. J., Chua, J. H., \& Litz, R. (2003). A unified systems perspective of family-owned firm performance: An extension and integration. Journal of Business Venturing, 18, 467-472.

Chrisman, J. J., \& Patel, P. C. (2012). Variations in R\&D investments of family and nonfamily firms: behavioral agency and myopic loss aversion perspectives. Academy of Management Journal, 55, 976-997.

Chua, J. H., Chrisman, J. J., \& De Massis, A. (2015, March). A closer look at socioemotional wealth: Its flows, stocks and prospects for moving forward. Entrepreneurship Theory and Practice, 39(2), 173-183.

Cruz, C., Firfiray, S., \& Gomez-Mejia, L.R. (2011). Socioemotional wealth and human resource management (HRM) in family-controlled firms. In A. Joshi, H. Liao, \& J. J. Martocchio (Eds.), Research in personnel and human resources management (pp. 159-217). Bingley, England: Emerald Group.

Cruz, C., Gomez-Mejia, L. R., \& Becerra, M. (2010). Perceptions of benevolence and the design of agency contracts: CEO-TMT relationships in family firms. Academy of Management Journal, 53, 69-89.

Cyert, R., \& March, J. G. (1992). A behavioral theory of the firm (2nd ed.). Hoboken, NJ: Wiley-Blackwell.

Datta, D. K., Guthrie, J. P., \& Wright P. M. (2005). Human resource management and labor productivity: Does industry matter? Academy of Management Journal, 48, 135-145.

De Kok, J. M. P., Uhlaner, L. M., \& Thurik, A. R. (2006). Professional HRM practices in family-owned-managed enterprises. Journal of Small Business Management, 44, 441-460.

Devers, C. E, McNamara, G., Wiseman, R. M., \& Arrfelt, M. (2008). Moving closer to the action: Examining compensation design effects on firm risk. Organization Science, 19(4), 548-566.

Dyer, W. G. Jr. \& Whetten, D. A. (2006). Family firms and social responsibility: Preliminary evidence from the S\&P 500. Entrepreneurship Theory and Practice, 30, 785-802.

Eisenhardt, K. M. (1989). Agency theory: An assessment and review. Academy of Management Review, 14, 57-74.

Fee, C. E., \& Hadlock, C. J. (2004). Management turnover across the corporate hierarchy. Journal of Accounting \& Economics, 37, 3-38.

Gerhart, B., \& Fang, M. (2014). Pay for (individual) performance: Issues, claims, evidence and the role of sorting effects. Human Resource Management Review, 24(1), 41-52.

Gomez-Mejia, L. R. (1983). Sex differences in occupational socialization. Academy of Management Journal, 26, 492-499.

Gomez-Mejia, L. R. (1984). Effect of occupation on task related, contextual and job involvement orientation: A cross-cultural perspective. Academy of Management Journal, 27, 706-720.

Gomez-Mejia, L. R. (1988). The role of human resources strategy in export performance: A longitudinal study. Strategic Management Journal, 8, 169-182.
Gomez-Mejia, L.R. (1992). Diversification, compensation strategy and firm performance. Strategic Management Journal, 13, 381-397.

Gomez-Mejia, L. R., \& Balkin, D. B. (1989). The effectiveness of individual and aggregate incentive plans in research and development units. Industrial Relations, 28, 431-445.

Gomez-Mejia, L. R., \& Balkin, D. B. (1992). The determinants of faculty pay: An agency theory perspective. Academy of Management Journal, 35, 1-36.

Gomez-Mejia, L. R., Berrone, P., \& Franco-Santos, M. (2010). Compensation and organizational performance: Theory, research, and practice. New York, NY: M. E. Sharpe.

Gomez-Mejia, L. R., Campbell, J. T., Martin, G., Hoskisson, R. E., Makri, M., \& Sirmon, D. G. (2014). Socioemotional wealth as a mixed gamble: Revisiting family firm R\&D investments with the behavioral agency model. Entrepreneurship Theory and Practice, 38, 1351-1374.

Gomez-Mejia, L. R., Cruz, C., Berrone, P., \& De Castro, J. (2011). The bind that ties: Socioemotional wealth preservation in family firms. Academy of Management Annals, 5, 653-707.

Gomez-Mejia, L. R., Haynes, K., Nuñez-Nickel, M., Jacobson, K., \& Moyano-Fuentes, J. (2007). Socioemotional wealth and business risks in family controlled firms: Evidence from Spanish olive oil mills. Administrative Science Quarterly, 52, 106-137.

Gomez-Mejia, L. R., Larraza-Kintana, M., \& Makri, M. (2003). The determinants of executive compensation in family-controlled public corporations. Academy of Management Journal, 46, 226-237.

Gomez-Mejia, L. R., Makri, M., \& Larraza-Kintana, M. (2010b). Diversification decisions in family-controlled firms. Journal of Management Studies, 47, 223-252.

Gomez-Mejia, L. R., Nuñez-Nickel, M., \& Gutiérrez, I. (2001). The role of family ties in agency contracts. Academy of Management Journal, 44, 81-96.

Gomez-Mejia, L. R., Page, R. C., \& Tornow, W. W. (1992). A comparison of the practical utility of traditional, statistical, and hybrid job evaluation approaches. Academy of Management Journal, 25 , 790-809.

Gomez-Mejia, L. R., Patel, P., \& Zellweger, T. (in press). In the horns of the dilemma: Socioemotional wealth, financial wealth, and acquisitions in family firms. Journal of Management.

Gomez-Mejia, L. R., Tosi, H. L., \& Hinkin, T. (1987). Managerial control, performance and executive compensation. Academy of Management Journal, 30, 51-70.

Gomez-Mejia, L. R., Welbourne, T., \& Wiseman, R. (2000). The role of risk sharing and risk taking under gainsharing. Academy of Management Review, 25(3), 492-589.

Gomez-Mejia, L. R., Wiseman, R. M., \& Johnson, B. (2005). Agency problems in diverse contexts: A global perspective. Journal of Management Studies, 42, 1507-1520.

Hair, J. F., Black, W. C., Babin, B. J., \& Anderson, R. E. (2009). Multivariate data analysis (7th ed.). Upper Saddle River, NJ: Prentice Hall.

Heck, R. K. Z. (1998). The entrepreneurial family: Refocusing on the family in business. In R. K. Z. Heck (Ed.), The entrepreneurial family (pp. 1-7). Needham, MA: Family Business Resources.

Huang, J., \& Kisgen, D. J. (2013). Gender and corporate finance: A male executives overconfident relative to female executives? Journal of Financial Economics, 108, 822-839.

Judge, T. A., \& Ferris, G. R. (1993). Social context of performance evaluation decisions. Academy of Management Journal, 36, 80-105.

Lamont, B. T., \& Anderson, C. R. (1985). Mode of corporate diversification and economic performance. Academy of Management Journal, 28, 926-933.

Laporta, R., López-de-Silanes, F., \& Shleifer, A. (1999). Corporate ownership around the world. Journal of Finance, 54, 471-517.

Larraza-Kintana, M., Wiseman, R. M., Gomez-Mejia, L. R., \& Welbourne, T. W. (2007). Distinguishing between employment and compensation risk influences on risk taking. Strategic Management Journal, 28, 1001-1119.

Lazear, E. P. (2000). The power of incentives. American Economic Review, $90,410-414$

Li, I., \& Hambrick, D. C. (2005). Factional groups: A new vantage on demographic faultlines, conflict, and disintegration in work teams. Academy of Management Journal, 48, 794-813. 
Lubatkin, M. H., Schulze, W. S., Ling, Y., \& Dino, R. N. (2005). The effects of parental altruism on the governance of family-managed firms. Journal of Organizational Behavior, 26, 313-330.

Makri, M., Lane, P. J., \& Gomez-Mejia, L. R. (2006). CEO incentives, innovation, and performance in technology-intensive firms: A reconciliation of outcome and behavior-based incentive schemes. Strategic Management Journal, 27, 1057-1080.

Martin, G. P., Gomez-Mejia, L. R. \& Wiseman, R. M. (2013). Executive stock options as mixed gambles: Revisiting the behavioral agency model. Academy of Management Journal, 56, 451-472.

Martin, G. P., Wiseman, R. M., \& Gomez-Mejia, L. R. (2016). Going shortterm or long term? CEO stock options and inter-temporal preferences in the presence of slack. Strategic Management Journal, 37, 2463-2480.

Martin, G. P., Wiseman, R. M., \& Gomez-Mejia, L. R. (2017). The interactive effect of monitoring and incentive alignment on agency costs. Journal of Management. doi:https://doi.org/10.1177/ 0149206316678453.

Mayer, R. C., Davis, J. H., \& Schoorman, F. D. (1995). An integrative model of organizational trust. Academy of Management Review, 20, 709-734.

McConaughy, D. L. (2000). Family CEOs versus non-family CEOs in the family controlled firm: An examination of the level and sensitivity of pay to performance. Family Business Review, 13, 121-131.

Milkovich, G. T., Newman, J., \& Gerhart, B. (2014). Compensation (11th ed.). New York, NY: McGraw-Hill//rwin.

Miller, D., \& Le-Breton-Miller, I. (2014, July). Deconstructing socioemotional wealth. Entrepreneurship Theory and Practice, 38, 713-720.

Miller, D., Le Breton-Miller, I., \& Scholnick, B. (2008). Stewardship vs. stagnation: An empirical comparison of small family and non-family businesses. Journal of Management Studies, 45, 51-78.

Miller, J. S., Wiseman, R. M., \& Gomez-Mejia, L. R. (2002). The fit between CEO compensation design and firm risk. Academy of Management Journal, 45, 745-756.

Mills, P. K., Chase, R. B., \& Marguiles, N. (1983). Motivating the client/ employee system as a service production strategy. Academy of Management Review, 8, 301-310.

Minichilli, A., Corbetta, G., \& MacMillan, I. C. (2010). Top management teams in family-controlled companies: Familiness, faultiness, and their impact on financial performance. Journal of Management Studies, 47, 205-222.

Muñoz-Bullón, F., \& Sánchez-Bueno, M. J. (2014). The use of incentive compensation among board members in family firms. Group \& Organization Management, 39, 162-189.

Murphy, K. R., \& Cleveland, J. N. (1991). Performance appraisal: an organizational perspective. Boston, MA: Allyn \& Bacon.

Narasimhan, R., Swink, M., \& Kim, S. W. (2006). Disentangling leanness and agility: A taxonomy of manufacturing plant performance. Journal of Operations Management, 24, 440-457.

Pearson, A.W., \& Marler, L. E. (2010). A leadership perspective of reciprocal stewardship in family firms. Entrepreneurship Theory and Practice, 34, 1117-1124.

Phillips, L. W. (1981). Assessing measurement error in key informant reports: A methodological note on organization analysis in marketing. Journal of Marketing Research, 18, 395-415.

Reid, R. S., \& Adams, J. S. (2001). Human resource management: A survey of practices within family and non-family firms. Journal of European Industrial Training, 25, 310-320.

Schulze, W. S., \& Kellermanns, F. W. (2015, March). Reifying socioemotional wealth. Entrepreneurship Theory and Practice, 39, 1-13.

Treviño, L. J., Gomez-Mejia, L. R., Balkin, D. B., \& Mixon, F. G. Jr. (in press). Meritocracies or masculinities? The differential allocation of named professorships by gender in the academy. Journal of Management. doi:https://doi.org/10.1177/0149206315599216

Vallejo, M. C. (2009). The effects of commitment of non-family employees of family firms from the perspective of stewardship theory. Journal of Business Ethics, 87, 379-390.

Vázquez-Bustelo, D., Avella, L., \& Fernández, E. (2007). Agility drivers, enablers and outcomes. Empirical test of an integrated agile manufacturing model. International Journal of Operations \& Production Management, 27, 1303-1332.
Verhoef, P. C., Langerak, F., \& Donkers, B. (2007). Understanding brand and dealer retention in the new car market: The moderating role of brand tier. Journal of Retailing, 83, 97-113.

Villena, V. H., Gomez-Mejía, L., \& Revilla, E. (2009). The decision of the supply chain executives to support or impede supply chain integration: A behavioral agency perspective. Decision Sciences, 40, 635-665.

Virany, B., Tushman, M. L., \& Romanelli, E. (1992). Executive succession and organization outcomes in turbulent environments: An organizational learning approach. Organization Science, 3, 72-91.

Werner, S., \& Tosi, H. L. (1995). Other people's money: The effects of ownership on compensation strategy and managerial pay. Academy of Management Journal, 38, 1672-1691.

Werner, S., Tosi, H. L., \& Gomez-Mejia, L. R. (2005). Organizational governance and employee pay: How ownership structure affects the firm's compensation strategy. Strategic Management Journal, 26, 377-384.

Westhead, P., \& Cowling, M. (1998). Family firm research: The need for a methodological rethink. Entrepreneurship Theory and Practice, 23, 31-56.

Wiseman, R. M., \& Bromiley, P. (1996). Toward a model of risk in declining organizations. Organization Science, 7, 524-543.

Wiseman, R. M., Cueva-Rodriguez, G., \& Gomez-Mejia, L. R. (2012). Towards a social theory of agency. Journal of Management Studies, 49, 202-222.

Wiseman, R. M., \& Gomez-Mejia, L. R. (1998). A behavioral agency model of managerial risk-taking. Academy of Management Review, 23, 133-153.

Wowak, A. J., Gomez-Mejia, L. R., Steinbach, A. L. (2017). Inducements and motives at the top: A holistic perspective on the drivers of executive behavior. Academy of Management Annals, 11, 1-33.

Zellweger, T. M., Nason, R. S., Nordqvist, M., \& Brush, C. G. (2013). Why do family firms strive for nonfinancial goals? An organizational identity perspective. Entrepreneurship Theory and Practice, 37, 229-248.

\section{AUTHOR'S BIOGRAPHIES}

LUIS R. GOMEZ-MEJIA is University Regents Professor and holds the Weatherup/Overby Chair of Management at the WP Carey School of Business, Arizona State University. Before that, he held endowed chair positions at University of Notre Dame, Texas A \& M, and Arizona State University. He has published 2,253 articles, many of them in the top management journals, and has received numerous awards for his research, including "Top 1 Percent of Most Highly Cited Researchers" by Thomson Reuters, Hall of Fame of Academy of Management, and "best paper" awards by the Academy of Management Journal and Administrative Science Quarterly.

MARTIN LARRAZA-KINTANA is Associate Professor of Management at Universidad Pública de Navarra, in Pamplona (Navarra), Spain. His research has always reflected his interest in people's decision-making behavior, particularly within organizations. Rooted in this primary interest, his most recent research touches such issues as entrepreneurship and employees' responses to human resource management policies, in addition to the influence of noneconomic utilities in the context of family-controlled firms. His research has been published in outlets such as the Academy of Management Journal, Strategic Management Journal, Human Resource Management, Administrative Science Quarterly, Journal of World Business, and Entrepreneurship Theory and Practice. 
JOSE MOYANO-FUENTES is Full Professor of Management at the Department of Business Organization, Marketing and Sociology at the University of Jaén (Spain). He currently conducts research on the role of human resource management in change contexts and interrelationships between lean production and supply chain management. His research has appeared in Administrative Science Quarterly, Journal of Management of Information Systems, Journal of Management Studies, International Journal of Management Reviews, International Journal of Human Resource Management, International Journal of Operations and Production Management, International Journal of Production Economics, Journal of Cleaner Production, and Technovation.

SHAINAZ FIRFIRAY is an Associate Professor in the Organization and Human Resource Management group at Warwick Business School, University of Warwick (United Kingdom). She received her $\mathrm{PhD}$ in management at IE Business School, Spain. Her research interests include work-life balance, social identity, diversity, and family firms.

How to cite this article: Gomez-Mejia L. R., LarrazaKintana M., Moyano-Fuentes J., and Firfiray S. Managerial Family Ties and Employee Risk Bearing in Family Firms: Evidence from Spanish Car Dealers. Hum Resour Manage. 2018;57:993-1007. https://doi.org/10.1002/hrm.21829

\section{APPENDIX}

\section{Items Included in the Employee Risk-Bearing Survey of Compensation Experts and Factor Analysis Results}

\begin{tabular}{lcc} 
& \multicolumn{2}{c}{ Factors } \\
\cline { 2 - 3 } Factors' Matrix & Factor & Factor \\
\hline
\end{tabular}

Item

1. Employees receive incentive payments if they $\quad .71 \quad .27$ show evidence that they have acquired new skills and knowledge to perform their jobs better.

2. Employees receive incentive payments if they show evidence that they can resolve important work-related problems.

3. Employees receive incentive payments when they $\quad \begin{array}{lll}.77 & -.07\end{array}$ achieve objectives or targets set by their employer.

4. Employees receive incentive payments based on $\quad .75 \quad-.16$ their individual performance as well as the performance of their team.

$\begin{array}{llll}5 . & \text { Internal candidates are given consideration over } & .02 & .57\end{array}$ external candidates for job openings.

6. The firm offers development opportunities to $\quad .14 \quad .83$ employees who wish to learn new knowledge and skills.

$\begin{array}{lll}\text { 7. Employees are encouraged to work with } & .00 & .77\end{array}$ community organizations.

8. Employees are encouraged to exchange their $\quad-.06 \quad .73$ opinions/ideas.

Factor average

3.592 .09

Cronbach's alpha

$.76 \quad .71$

